Penelitian

\title{
Karakteristik Morfologi Rusa timor (Rusa timorensis) dengan Pemeliharaan Ex Situ di Kota Kupang
}

\author{
Morphology Characteristics of Timor Deer (Rusa timorensis) with Ex Situ \\ Conservation Condition in Kupang City
}

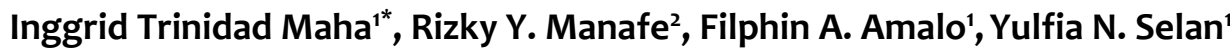 \\ ${ }^{1}$ Departemen Anatomi, Fisiologi, Farmakologi dan Biokimia \\ Fakultas Kedokteran Hewan Universitas Nusa Cendana, Kupang \\ ${ }^{2}$ Fakultas Kedokteran Hewan Universitas Nusa Cendana, Kupang \\ *Penulis untuk korespondensi: inggridiong@gmail.com \\ Diterima 27 Juni 2020, Disetujui 12 Januari 2021
}

\begin{abstract}
ABSTRAK
Rusa merupakan salah satu sumber daya genetik yang ada di Indonesia. Keberadaan populasi rusa timor semakin menurun sebagai akibat adanya perburuan liar untuk berbagai kepentingan. Usaha yang dilakukan agar populasi rusa di alam tetap lestari ialah dengan melakukan pengembangan rusa timor melalui konservasi ex situ. Penelitian ini bertujuan untuk mengetahui karakteristik morfologi rusa timor dan sistem pemeliharaan pada penangkaran di Kota Kupang. Sampel yang digunakan adalah 35 ekor rusa timor yang dipelihara pada dua penangkaran di Kota Kupang. Metode yang digunakan adalah metode observasi, wawancara, dan pengukuran menggunakan pita ukur meliputi: pengukuran panjang badan $(\mathrm{cm})$, tinggi badan $(\mathrm{cm})$, lingkar dada $(\mathrm{cm})$, panjang ekor $(\mathrm{cm})$, panjang telinga $(\mathrm{cm})$, panjang kepala $(\mathrm{cm})$, panjang ranggah $(\mathrm{cm})$, dan bobot badan $(\mathrm{kg})$ menggunakan rumus winter. Hasil penelitian menunjukkan adanya perbedaan antara rusa timor jantan dan betina. Secara morfologi, rusa timor jantan memiliki warna dasar kuning kecoklatan pada seluruh area tubuh dan tidak memiliki corak tertentu, sedangkan rusa timor betina memiliki warna coklat, dan berwarna coklat keabuan pada area ventral yaitu bagian kaki, perut, dagu dan bagian bawah leher. Secara morfometri, menunjukan adanya perbedaan nyata pada bagian-bagian luar tubuh rusa jantan dan betina yaitu : bobot badan, lingkar dada, panjang badan, dan tinggi badan. Rusa timor dewasa di Kota Kupang memiliki ukuran tubuh yang lebih besar dibandingkan rusa timor dewasa di Manokwari. Anak rusa timor di Kota Kupang memiliki ukuran tubuh yang lebih besar bila dibandingkan dengan anak rusa timor di Ciawi. Sistem pemeliharaan rusa timor pada dua kawasan penangkaran di Kota Kupang merupakan penangkaran semi terkurung (mini ranch) yang dipelihara di area pekarangan rumah.
\end{abstract}

Kata kunci: Rusa timor, karakteristik morfologi, morfometri, penangkaran, ex situ

\begin{abstract}
Deer are one of the genetic resources in Indonesia. The existence of the Timor deer population is decreasing as a result of illegal hunt for various purpose. Efforts are being made so that the deer population in nature remains sustainable, is by developing timor deer through ex situ conservation. This study aims to determine the morphological characteristics of timor deer and maintenance systems in captivity in Kupang city. The sample used 35 Timor deer kept in two captivity in the city of Kupang. The method used observation method, interviews, and measurements using measuring tape includes: measurement of body length $(\mathrm{cm})$, height $(\mathrm{cm})$, chest circumference $(\mathrm{cm})$, tail length $(\mathrm{cm})$, ear length $(\mathrm{cm})$, head length $(\mathrm{cm})$, partner length $(\mathrm{cm})$, and body weight $(\mathrm{kg})$ using the winter formula. The results showed the difference between male and female timor deer. Morphologically, male timor deer has a brownish-yellow base color in all areas of the body and does not have a certain pattern, while female timor deer has a brown color, and grayish brown in the ventral area such as the legs, abdomen, chin and lower neck. By morphometry, there are significant differences in the outer parts of the body of male and female deer such as: body weight, chest circumference, body length, and height. Adult timor deer in Kupang city has a larger body size than adult timor deer in Manokwari. Timor deer calves in the city of Kupang have a larger body size when compared to timor deer calves in Ciawi. The timor deer rearing system in two captivity areas in Kupang city is a semi-confinement breeding (mini farm) that is maintained in the area of the house yard.
\end{abstract}

Keywords: Timor deer, characteristic morphology, morphometry, breeding, ex situ 


\section{PENDAHULUAN}

Rusa merupakan salah satu sumber daya genetik yang ada di Indonesia. Terdapat empat spesies rusa endemik di Indonesia yaitu: rusa sambar (Cervus unicolor), rusa timor (Rusa timorensis), rusa bawean (Axix kuhli) dan muncak (Muntiacus muntjak). Rusa timor (Rusa timorensis) termasuk jenis rusa yang mudah beradaptasi dengan lingkungan di luar habitatnya dibandingkan jenis rusa lainnya (Thohari et al., 2011). Rusa awalnya merupakan satwa liar akan tetapi saat ini pemerintah telah melakukan perlindungan dengan menetapkan status rusa sebagai hewan liar yang dapat didomestikasi melalui SK Menteri Pertanian No 362/KPTS/TN/12/V/1990 pada tanggal 20 Mei 1990.

Rusa timor (Rusa timorensis) merupakan salah satu keanekaragaman dan kekayaan satwa yang ada di NTT, namun sayangnya keberadaan populasi rusa timor semakin menurun sebagai akibat adanya perburuan liar untuk berbagai kepentingan. Masyarakat NTT mengkonsumsi daging rusa sebagai salah satu sumber protein. Menurut Maharani dan siswadi (2017), pemanfaatan rusa dapat dilihat sebagai salah satu sumber pemenuhan kebutuhan protein masyarakat karena rusa mempunyai potensi sebagai penghasil daging dengan kualitas tinggi, kadar lemak rendah dan harga yang tinggi pada segmen pasar tertentu. Selain diburu, pertambahan jumlah penduduk serta penyempitan habitat asli rusa mengakibatkan penurunan populasi. Usaha yang dilakukan agar populasi rusa di alam tetap lestari, diantaranya melalui konservasi ex situ atau sering disebut juga kegiatan penangkaran yang didukung pemerintah dengan mengeluarkan Peraturan Menteri Kehutanan (Permenhut) No. P.19/MenhutII/2005 Tanggal 19 Juli 2005 tentang Penangkaran Tumbuhan dan Satwa Liar.

Rusa Timor mempunyai ukuran tubuh kecil, dahi cekung, tungkai pendek, gigi seri relatif besar, ekor panjang, dan bulu atau rambut berwarna coklat kekuning-kuningan. Rusa jantan memiliki ranggah yang relatif besar, ramping, panjang dan bercabang (Schroder, 1976; Thohari et al., 2011). Rusa betina tidak memiliki ranggah, ukuran tubuh yang lebih kecil, dan memiliki waktu kebuntingan selama 8 bulan, dengan jumlah kelahiran tunggal. Keragaman genetik ternak dalam suatu wilayah yang telah beradaptasi dengan lingkungan dalam wilayah tersebut sangat potensial dikembangkan. Dengan demikian, sangat perlu mengetahui karakteristik morfologi rusa timor (Rusa timorensis) yang ada di $\mathrm{NTT}$, sehingga data yang didapat bisa dimanfaatkan sebagai informasi dasar dalam pengembangan produktivitas ternak rusa timor di NTT.

\section{BAHAN DAN METODE}

Pengambilan data dilakukan di dua responden yang berada di sekitar Kota Kupang yang memelihara rusa dengan pola pemeliharaan ex situ. Alat yang digunakan dalam penelitian ini antara lain kamera, bolpoin, buku, kandang jepit dan pita ukur. Sementara bahan yang digunakan yaitu 35 ekor rusa timor. Metode yang digunakan adalah metode survei dengan mengunjungi dua responden yang memelihara rusa timor. Observasi dan wawancara semi struktural, Survei awal dilakukan untuk mengumpulkan informasi lokasi penangkar yang memelihara rusa di Kota Kupang. Pengamatan langsung di lapangan meliputi identifikasi jenis kelamin rusa dan pendugaan umur. Pengumpulan informasi tata laksana pemeliharaan rusa dilakukan melalui wawancara terhadap penangkar. Penelitian ini telah mendapat persetujuan dari Komisi Etik Hewan Fakultas Kedokteran Hewan Undana yang terlampir dengan Surat Kelayakan Etik Hewan No.KEH/FKH/NPEH/011/2019.

\section{Variabel Pengamatan}

\section{Pola warna rambut}

Pengamatan secara visual sebaran pola warna pada seluruh badan mulai dari kepala sampai kaki. Sebaran pola warna dibagi ke dalam warna dasar dominan dan warna belang. Observasi dilakukan dengan pengambilan gambar atau foto menggunakan kamera. Pengamatan pola wama rambut dilakukan untuk melengkapi pengamatan karakteristik morfologi yang lain.

Umur

Pendugaan umur rusa dilakukan dengan memperhatikan formula dan struktur gigi dengan acuan Djanah (1984) dengan memperhatikan struktur pertumbuhan gigi seri.

\section{Karakteristik morfologi rusa timor}

Pengamatan karakteristik morfometri dilakukan terhadap beberapa karakter tubuh bagian luar yang dianggap mewakili karakteristik diantaranya: Pengukuran panjang badan $(\mathrm{cm})$, tinggi badan $(\mathrm{cm})$, lingkar dada $(\mathrm{cm})$, panjang ekor $(\mathrm{cm})$, panjang telinga $(\mathrm{cm})$, panjang kepala $(\mathrm{cm})$, panjang ranggah $(\mathrm{cm})$, bobot badan (kg) yang akan dihitung menggunakan rumus winter. Dalam pelaksanaannya rusa dimasukkan dalam kandang jepit sehingga memudahkan untuk mengontrol pergerakannya dan pengukuran karakteristik morfologi dapat dilakukan dengan baik. 


\section{Sistem Pemeliharaan}

Pengamatan terhadap sistem pemeliharaan dilakukan dengan mengunjungi dua responden yang memelihara rusa timor. Wawancara semi struktual terhadap para peternak dilakukan untuk mengetahui teknik pemeliharaan rusa oleh responden. Data yang diperoleh dari hasil penelitian dianalisis secara deskriptif dan menggunakan program Microsoft Excel untuk mendapatkan nilai rata-rata dan standar deviasi selanjutnya data disajikan dalam bentuk tabel dan gambar.

\section{HASIL}

\section{Morfologi Rusa Timor}

\section{Warna rambut}

Berdasarkan hasil pengamatan yang dilakukan pada dua (2) penangkaran, rusa timor jantan memiliki warna dasar kuning kecoklatan pada seluruh area tubuh dan tidak memiliki corak tertentu (Gambar 1A). Pada rusa betina terdapat sedikit perbe-
Karakteristik Morfologi Rusa timor (Rusa timorensis) | 3

daan yaitu memiliki warna coklat, dan pada area ventral yaitu bagian kaki, perut, dagu dan bagian bawah leher berwarna coklat keabuan (Gambar 1B).

\section{Pendugaan umur}

Pendugaan umur penting dilakukan untuk mengetahui umur rusa serta untuk mengetahui masa produktivitas ternak. Pendugaan umur pada penelitian ini dilakukan dengan melakukan wawancara terhadap peternak dan dengan mengacu pada metode pendugaan umur menurut Djanah (1984) yaitu dengan melihat struktur ertumbuhan gigi seri. Populasi rusa timor berdasarkan pengelompokan umur di dua (2) penangkaran dapat dilihat pada Tabel 1. Berdasarkan penelitian ini pengelompokan rusa dewasa berdasarkan umur $>2$ tahun dan pengelompokan anak rusa berdasarkan umur $<2$ tahun.

\section{Morfometri rusa timor}

Berdasarkan Tabel $2 a$ dan $2 b$ terlihat bahwa terdapat perbedaan yang besar pada beberapa bagian tubuh rusa jantan dewasa dan betina dewasa
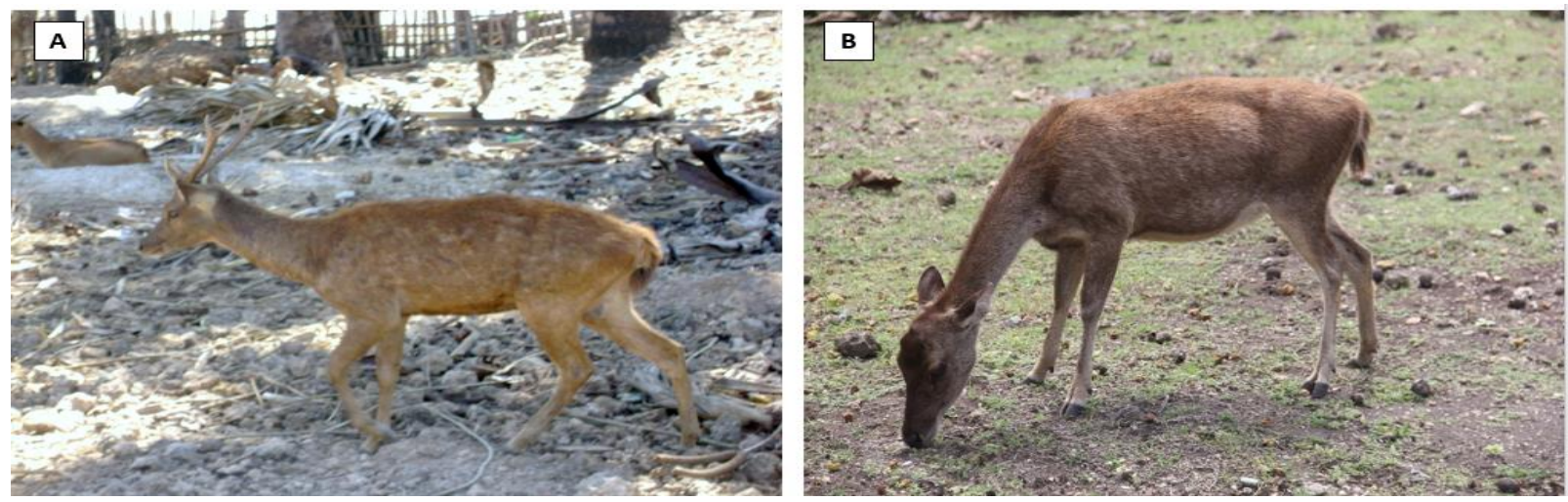

Gambar 1 A) Rusa Timor Jantan; B) Rusa Timor Betina
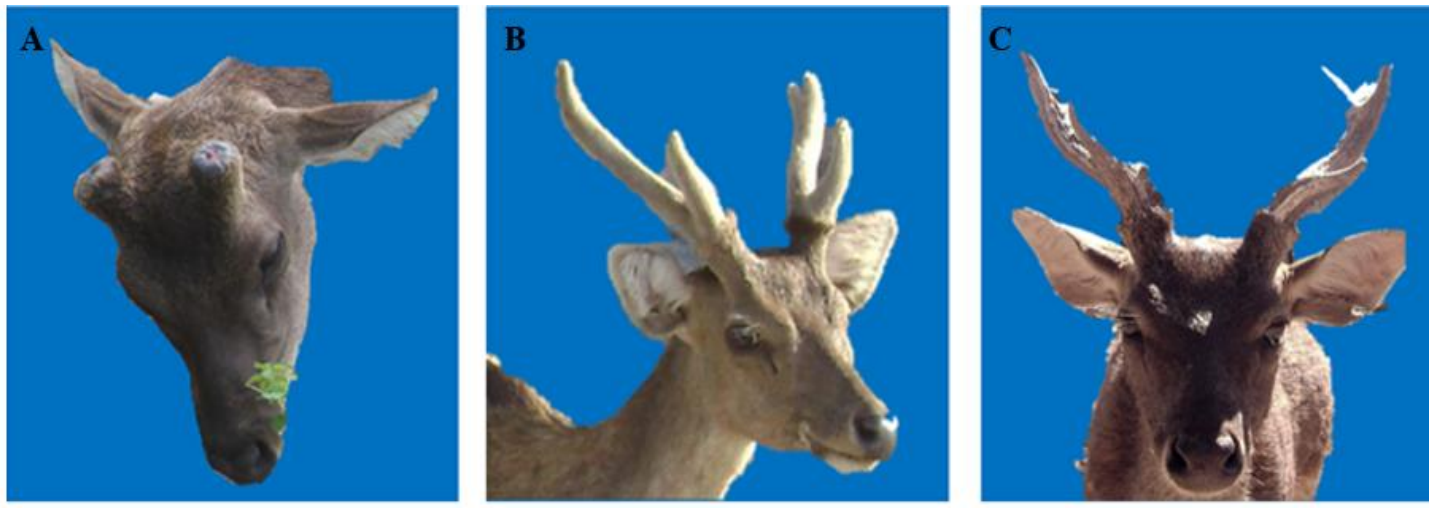

Gambar 2 Ranggah Rusa Timor Jantan. Ranggah Pedicle (A), Ranggah muda (B), Ranggah Keras (C) 
4 | Maha et al.

Tabel 1 Populasi Rusa Timor pada kawasan penangkaran I dan II

\begin{tabular}{ccccc}
\hline \multirow{2}{*}{ No } & & Rusa Timor & \multicolumn{2}{c}{ Kawasan Penangkaran } \\
\cline { 3 - 5 } & & I & II \\
\hline 1 & Jantan Dewasa & 7 & 1 \\
2 & Betina Dewasa & 10 & 5 \\
3 & Anak Jantan & 3 & 1 \\
4 & Anak Betina & 6 & 2 \\
\hline & & Total & 26 & 9 \\
\hline
\end{tabular}

Tabel 2a Rerata morfometri rusa timor dewasa pada kawasan penangkaran I di Kota Kupang

\begin{tabular}{lccc}
\hline \multicolumn{1}{c}{ Parameter } & $\hat{\sigma}$ & $q$ & Standar Deviasi $\hat{\jmath}$ dan + \\
\hline Panjang badan $(\mathrm{cm})$ & $74,7 \pm 2,19$ & $59,4 \pm 1,96$ & 7,66 \\
Tinggi badan $(\mathrm{cm})$ & $79,3 \pm 2,43$ & $64,9 \pm 2,74$ & 7,19 \\
Lingkar dada $(\mathrm{cm})$ & $94,7 \pm 3,45$ & $77,6 \pm 4,20$ & 8,56 \\
Panjang kepala $(\mathrm{cm})$ & $27,6 \pm 1,29$ & $20,1 \pm 1,81$ & 3,74 \\
Panjang ekor $(\mathrm{cm})$ & $23,6 \pm 1,99$ & $17,7 \pm 2,19$ & 2,94 \\
Panjang telinga $(\mathrm{cm})$ & $13,0 \pm 1,31$ & $11,2 \pm 1,08$ & 0,90 \\
Panjang ranggah & $26,1 \pm 6,87$ & - & - \\
(cm) & $67,2 \pm 6,46$ & $35,9 \pm 4,24$ & 15,65 \\
Bobot badan $(\mathrm{kg})$ & & & \\
\hline
\end{tabular}

Tabel 2b Rerata morfometri rusa timor dewasa pada kawasan penangkaran II di Kota Kupang

\begin{tabular}{lccc}
\hline \multicolumn{1}{c}{ Parameter } & $\hat{1}$ & $q$ & Standar Deviasi $\hat{\jmath}$ dan + \\
\hline Panjang badan $(\mathrm{cm})$ & 75 & $59,8 \pm 2,48$ & 7,60 \\
Tinggi badan $(\mathrm{cm})$ & 80 & $65,6 \pm 4,03$ & 7,20 \\
Lingkar dada $(\mathrm{cm})$ & 101 & $80,0 \pm 3,85$ & 10,50 \\
Panjang kepala $(\mathrm{cm})$ & 28 & $21,2 \pm 3,12$ & 3,40 \\
Panjang ekor $(\mathrm{cm})$ & 25 & $19,0 \pm 2,68$ & 3,00 \\
Panjang telinga $(\mathrm{cm})$ & 15 & $11,4 \pm 1,36$ & 1,80 \\
Panjang ranggah $(\mathrm{cm})$ & 34 & - & - \\
Bobot Badan $(\mathrm{kg})$ & 76,5 & $38,5 \pm 5,04$ & 19,01 \\
\hline
\end{tabular}

pada kedua penangkaran yaitu bobot badan,lingkar dada, panjang badan, dan tinggi badan. Rerata morfometri rusa timor dewasa dapat dilihat pada Tabel 2 dan rerata morfometri anak rusa timor dapat dilihat pada Tabel 3. Pada Tabel 3a terlihat adanya perbedaan yang cukup besar antara anak rusa jantan dan betina di penangkaran I yaitu tinggi badan, lingkar dada, bobot badan dan panjang badan.

Perbedaan antara anak rusa jantan dan betina pada penangkaran II yang disajikan pada Tabel za tidak menunjukan perbedaan yang nyata. Hal ini sesuai dengan penelitian sebelumnya yang dilakukan Adiati dan Brahmantiyo (2015) di Ciawi dan Pattiselanno et al. (2008) di Manokwari bahwa keseluruhan morfometri anak jantan dan anak betina relatif sama. Berbeda dengan hasil penelitian yang terlihat pada Tabel $3 \mathrm{~b}$, ada perbedaan yang nyata antara rusa jantan dan betina pada tinggi badan, bobot badan, lingkar dada, dan panjang badan. Hal ini dikarenakan, populasi anak rusa pada penangkaran Il yaitu satu (1) ekor rusa jantan berusia $<1$ tahun dan dua (2) ekor rusa betina berusia 1 tahun dan $<1$ tahun. Berdasarkan hasil penelitian diketahui adanya hubungan antara peningkatan umur yang berban- 
ding lurus dengan peningkatan sifat-sifat kuantitatif. Secara fisiologis, pertambahan umur sejalan dengan peningkatan ukuran tubuh akibat dari proses pertumbuhan (Bukhoriet et al., 2017).

Berdasarkan hasil penelitian, anak rusa timor \pm 1 tahun sudah mengalami pertumbuhan ranggah yang dimulai dengan pertumbuhan ranggah pada tahap pedisel (pedicle) (Gambar 2A). Terlihat juga rusa timor dengan ranggah muda (velvet) (Gambar 2B), dan ranggah keras (Gambar $2 \mathrm{C}$ ). Ranggah utama terpanjang rusa timor yaitu $35 \mathrm{cmpada}$ usia 6 tahun (Tabel 4 ).

\section{Panjang badan rusa}

Rerata panjang badan rusa jantan dewasa di penangkaran I adalah $74,7 \pm 2,19 \mathrm{~cm}$ tidak jauh berbeda dengan rusa jantan di penangkaran II yaitu $75 \mathrm{~cm}$. Pada rusa betina di penangkaran I adalah 59,4 $\pm 1,96$ $\mathrm{cm}$ dan di penangkaran II yaitu 59,8 $\pm 2,48 \mathrm{~cm}$, memiliki hasil yang tidak jauh berbeda. Perbandingan panjang badan anak rusa yang ditampilkan pada Tabel $3 a$ dan $3 b$ tidak memiliki perbedaan yang besar, memiliki kesamaan dengan penelitian yang dilakukan Adiati dan Brahmantiyo (2015) dan Pattiselanno et al. (2008).
Tinggi badan rusa

Berdasarkan hasil penelitian yang dilakukan (pada Tabel 2a dan 2b) terlihat bahwa rata-rata tinggi badan rusa jantan dewasa yaitu 79,3 $\pm 2,43 \mathrm{~cm}$ dan $80 \mathrm{~cm}$, berbeda dengan rata-rata tinggi badan rusa betina yaitu $64,9 \pm 2,74 \mathrm{~cm}$ dan65,6 $\pm 4,03 \mathrm{~cm}$. Berbeda dengan tinggi badan rusa sambar yang dilaporkan Bismark et al. (2011) yang mencapai kisaran 120-150 cm. Tinggi badan anak rusa yang terlihat pada Tabel $3 a$ dan $3 \mathrm{~b}$ tidak jauh berbeda pada rusa jantan $52,3 \pm 10,3 \mathrm{~cm}$ dan $48,00 \mathrm{~cm}$, sedangkan anak rusa betina 53,8 $\pm 5,55$ dan 54,0 \pm $6,00 \mathrm{~cm}$. Dengan demikian, laju pertumbuhan tinggi badan rusa jantan lebih cepat dibandingkan dengan rusa betina akibat pertambahan usia.

\section{Lingkar dada rusa}

Berdasarkan hasil penelitian, lingkar dada rusa jantan di penangkaran I adalah 94,7 $\pm 3,45 \mathrm{~cm}$ dan di penangkaran II yaitu $101 \mathrm{~cm}$. Sedangkan, lingkar dada rusa betina di penangkaran I adalah 77,6 \pm 4,20 $\mathrm{cm}$ dan di penangkaran II yaitu $80,0 \pm 3,85 \mathrm{~cm}$. Hasil ini memiliki kemiripan dengan lingkar dada rusa timor di Manokwari berdasarkan penelitian yang dilakukan Pattiselanno et al. (2008) yaitu rata-rata lingkar dada rusa jantan $96,86 \pm 3,40 \mathrm{~cm}$ dan rusa

Tabel za Rerata morfometri anak rusa timor pada kawasan penangkaran I di Kota Kupang

\begin{tabular}{lccc}
\hline \multicolumn{1}{c}{ Parameter } & $\hat{0}$ & $q$ & Standar Deviasin $\delta^{\uparrow}$ dan $q$ \\
\hline Panjang badan $(\mathrm{cm})$ & $46,7 \pm 5,73$ & $47,0 \pm 2,94$ & 0,167 \\
Tinggi badan $(\mathrm{cm})$ & $52,3 \pm 10,3$ & $53,8 \pm 5,55$ & 0,750 \\
Lingkar dada $(\mathrm{cm})$ & $59,3 \pm 8,73$ & $56,2 \pm 4,67$ & 1,583 \\
Panjang kepala $(\mathrm{cm})$ & $19,7 \pm 4,11$ & $19,3 \pm 2,75$ & 0,167 \\
Panjang ekor $(\mathrm{cm})$ & $14,3 \pm 3,30$ & $16,0 \pm 3,42$ & 0,833 \\
Panjang telinga $(\mathrm{cm})$ & $9,7 \pm 0,47$ & $10,3 \pm 1,37$ & 0,333 \\
Panjang ranggah $(\mathrm{cm})$ & $7,0 \pm 0,00$ & - & - \\
Bobot Badan $(\mathrm{kg})$ & $17,4 \pm 7,24$ & $15,1 \pm 3,48$ & 1,150 \\
\hline
\end{tabular}

Tabel 3b Rerata morfometri anak rusa timor pada kawasan penangkaran II di Kota Kupang

\begin{tabular}{lccc}
\hline \multicolumn{1}{c}{ Parameter } & $\hat{r}$ & $q$ & Standar Deviasi $\hat{\text { dan }}+$ \\
\hline Panjang badan $(\mathrm{cm})$ & 45 & $47,5 \pm 5,50$ & 1,25 \\
Tinggi badan $(\mathrm{cm})$ & 48 & $54,0 \pm 6,00$ & 3,00 \\
Lingkar dada $(\mathrm{cm})$ & 55 & $58,0 \pm 8,00$ & 1,50 \\
Panjang kepala $(\mathrm{cm})$ & 18 & $17,0 \pm 2,00$ & 0,50 \\
Panjang ekor $(\mathrm{cm})$ & 15 & $15,0 \pm 3,00$ & 0,00 \\
Panjang telinga $(\mathrm{cm})$ & 10 & $10,5 \pm 2,50$ & 0,25 \\
Panjang ranggah $(\mathrm{cm})$ & 3 & - & - \\
Bobot Badan $(\mathrm{kg})$ & 13,6 & $16,8 \pm 6,30$ & 1,60 \\
\hline
\end{tabular}


6 | Maha et al.

Tabel 4 Morfometri ranggah rusa timor jantan pada kawasan penangkaran I dan II di Kota Kupang

\begin{tabular}{cccc}
\hline No & Umur & Panjang Ranggah & Tahapan Ranggah \\
\hline 1 & $<$ tahun** & $3 \mathrm{~cm}$ & Pesidel \\
2 & 1 tahun* & $7 \mathrm{~cm}$ & Pesidel \\
3 & 2 tahun* & $13 \mathrm{~cm}$ & ranggah muda \\
4 & 3 tahun* & $19 \mathrm{~cm}$ & ranggah keras \\
5 & 4 tahun* & $25 \mathrm{~cm}$ & ranggah keras \\
6 & 4 tahun* & $27 \mathrm{~cm}$ & ranggah keras \\
7 & 5 tahun* & $31 \mathrm{~cm}$ & ranggah keras \\
8 & 5 tahun* & $33 \mathrm{~cm}$ & ranggah keras \\
9 & 5 tahun** & $34 \mathrm{~cm}$ & ranggah keras \\
10 & 6 tahun* & $35 \mathrm{~cm}$ & ranggah keras \\
\hline
\end{tabular}

Keterangan : * Kawasan penangkaran I ; ** = Kawasan penangkaran II

betina $80,43 \pm 7,04 \mathrm{~cm}$. Rata-rata lingkar dada anak rusa jantan dan betina tidak terlalu berbeda (Tabel $3 a$ dan 3 b) dengan koefisien variasi $1,58 \mathrm{~cm}$ dan 1,50 $\mathrm{cm}$. Tidak jauh berbeda dengan yang dilaporkan oleh Adiati dan Brahmantiyo (2015) dan pada anak rusa timor di Ciawi, perbedaan lingkar dada anak rusa jantan dan betina $0,96 \mathrm{~cm}$.

\section{Panjang ranggah rusa}

Berdasarkan hasil penelitian, ranggah utama terpanjang rusa timor yaitu $35 \mathrm{cmpada}$ usia 6 tahun. Namun lebih pendek dibandingkan dengan panjang ranggah rusa timor di Bogor (Handarini, 2006) yaitu panjang ranggah utama $63 \mathrm{~cm}$. Penelitian yang dilakukan oleh Semiadi (1997) menunjukan adanya perbedaan panjang ranggah pada beberapa subspesies rusa timor (Cervus timorensis) dewasa dengan hasil panjang ranggah utama yaitu: C.t. timorensis; $36.6 \mathrm{~cm}$, C.t. macassaricus; $45.3 \mathrm{~cm}$, C.t. floresiensis; $42.6 \mathrm{~cm}$, C.t. moluccensis; $54.7 \mathrm{~cm}$, dan C.t. russa; $78.8 \mathrm{~cm}$.

\section{Bobot badan rusa}

Berdasarkan hasil penelitian, rata-rata bobot badan rusa jantan di penangkaran ladalah $67,2 \pm$ $6,46 \mathrm{~kg}$ dan di penangkaran II yaitu $76,5 \mathrm{~kg}$. Penelitian terdahulu yang dilakukan di Bogor oleh Thohari et al. (2011) yaitu bobot badan rusa timor jantan berkisar antara 40-120kg, dibandingkan dengan bobot badan rusa sambar (Cervus unicolor) yaitu $276 \mathrm{~kg}$ (Geist, 1998). Menurut Takandjandji dan Garsetiasih (2002), rusa timor jantan dewasa di NTT memiliki bobot badan dengan kisaran antara 50 - 70 kg dengan rata-rata berat karkas $44,3-62,0 \%$ dari bobot badan atau 20,0 - 31,0 kg.
Rata-rata bobot badan rusa timor betina dewasa di penangkaran ladalah $35,9 \pm 4,24 \mathrm{~kg}$ dan di penangkaran II yaitu 38,5 $\pm 5,04 \mathrm{~kg}$, sedikit lebih besar dibandingkan bobot badan rusa timor di Manokwari yaitu 30-35,7 kg (Pattiselanno et al., 2008). Namun, lebih rendah dibandingkan dengan rusa timor betina dewasa yang ada di area wisata Balitnak yaitu 54,75 kg (Adiati \& Brahmantiyo, 2015). Bobot badan suatu ternak memiliki hubungan dengan peningkatan ukuran tubuh seperti panjang badan, tinggi badan serta lingkar dada.

Rerata bobot badan anak rusa jantan di penangkaran ladalah 17,4 \pm 7,24 kg dan di penangkaran II yaitu $13,6 \mathrm{~kg}$ sedangkan anak rusa betina di penangkaran ladalah 15,1 3,48 dan di penangkaran II yaitu $16,8 \pm 6,30 \mathrm{~kg}$.

\section{Sistem Pemeliharaan}

Lingkungan penangkaran

Berdasarkan hasil penelitian pada dua kawasan penangkaran, sistem penangkaran yang diterapkan adalah penangkaran semi terkurung (mini ranch) yang berlokasi di pekarangan rumah. Kedua kawasan penangkaran berada pada wilayah pemukiman warga. Dalam sistem pemeliharaannya, rusa timor dipelihara bersamaan dengan beberapa ternak lainnya seperti babi, ayam dan kambing. Sanitasi pada kedua kawasan penangkaran kurang diperhatikan. Hal ini terlihat dari tidak dilakukannya pembersihan secara rutin dan juga pembersihan tanpa disertai desinfektan.

\section{Aktivitas rusa}

Berdasarkan hasil penelitian menunjukkan bahwa aktivitas rusa dimulai dari pagi pukul 07.00 WITA 
hingga sore hari pukul 17.00 WITA meliputi aktivitas: makan, minum, istirahat, dan bergerak. Berdasarkan wawancara yang dilakukan terhadap peternak, peningkatan aktivitas rusa terjadi pada musim kawin pada bulan Maret hingga November. Pada penangkaran I terdapat 7 ekor pejantan cenderung melakukan perkelahian pada musim kawin untuk mendapatkan 10 betina, sedangkan pada penangkaran II terdapat 1 ekor jantan yang menguasai 5 ekor betina.

\section{Manajemen Pakan}

Berdasarkan hasil penelitian, pakan yang disediakan terdiri dari $75 \%$ dedaunan dan ranting muda, serta $25 \%$ rerumputan.Jenis dedaunan yang diberikan yaitu angsana atau sonokembang (Pterocarpus indicus), kangkung (Ipomoea aquatica Forsk.), lamtoro (Leucaena leucocephala), dan gamal (Gliricidia sepium) sedangkan jenis rumput antara lain rumput lapangan, alang-alang (Imperata cylindrica) dan rumput gajah (Penisetum purpureum) serta terdapat pakan tambahan yang tersedia seperti buah lontar (Borassus flabellifer) yang terdapat pada area tempat rusa diumbar di penangkaran I. Berdasarkan pengamatan yang dilakukan, teknik pemberian pakan tidak menggunakan tempat pakan dan frekuensi pemberian pakan hanya satu (1) kali dalam sehari dengan jumlah yang tidak menentu.

\section{Manajemen Reproduksi}

Berdasarkan hasil wawancara yang dilakukan terhadap peternak, manajemen reproduksi yang dilakukan pada kedua penangkaran kurang diperhatikan sehingga rusa timor memiliki pola perkawinan inbreeding dengan jumlah kelahiran 1-2 ekor dalam setahun.

\section{PEMBAHASAN}

\section{Morfologi Rusa Timor}

\section{Warna rambut}

Warna adalah kesan yang ditangkap oleh mata dari cahaya yang dipantulkan oleh benda-benda di sekitar (Wiwid, 2016). Warna yaitu sifat yang tidak dapat diukur, namun dapat dikelompokkan dengan jelas yang dikendalikan oleh satu atau dua pasang gen dan sedikit sekali dipengaruhi oleh keadaan lingkungan (Hardjosubroto, 1994).Warna rambut sangat besar dipengaruhi oleh genetik yang diturunkan (Bowling \& Ruvinsky, 2000). Pola warna rambut rusa timor Kupang yang diamati tidak jauh berbeda dengan hasil penelitian Pattiselanno et al. (2008) terhadap rusa timor di Manokwari. Sedangkan, bila dibandingkan dengan rusa asli Indonesia lainnya memiliki pola warna yang berbeda seperti muncak (Muntiacus muntjak) yang berwarna merah keemasan (Oka, 1998), rusa sambar (Cervus unicolor) yang berwarna coklat kehitaman (Idris, 2000), dan rusa bawean (Axix kuhli) berwarna kekuningan (Stefoff, 2008).

Pendugaan umur

Pendugaan umur penting dilakukan untuk mengetahui umur rusa serta untuk mengetahui masa produktivitas ternak. Pendugaan umur pada penelitian ini dilakukan dengan melakukan wawancara terhadap peternak dan dengan mengacu pada metode pendugaan umur menurut Djanah (1984) yaitu dengan melihat struktur pertumbuhan gigi seri. Menurut Thohari et al. (2011), usia produktif rusa timor yaitu 18-24 bulan. Pada usia tersebut rusa timor sudah memiliki kematangan kelamin sehingga dikategorikan sebagai rusa dewasa yang siap produksi.

Rusa jantan dewasa memiliki ranggah bercabang yang merupakan salah satu tampilan karakter seksual sekunder yang khas pada rusa jantan setelah memasuki pubertas (Handarini, 2006). Rusa betina dewasa memiliki kematangan seksual dimulai pada usia 18 bulan dipengaruhi oleh kondisi lingkungan dan nutrisi dengan usia kebuntingan selama 8 bulan (Mahre et al., 2016). Rusa mampu bertahan hidup hingga umur 15-20 tahun dengan lama masa reproduksi dimulai dari umur 1,5 tahun sampai 12 tahun (Mahre et al., 2016).

\section{Morfometri rusa timor}

Morfometri adalah pengukuran bentuk dan struktur luas untuk pencirian suatu analisis kuantitatif. Pengukuran morfometri pada penelitian ini dilakukan pada 23 ekor rusa timor dewasa, dan 12 ekor anak rusa timor pada dua (2) penangkaran di kota Kupang dengan menggunakan pita ukur dan dilakukan di dalam kandang jepit. Perbedaan yang besar antara rusa jantan dan rusa betina ini memiliki kemiripan dengan hasil penelitian yang telah dilakukan oleh Pattiselanno et al. (2008) pada rusa timor di Manokwari, bahwa perbedaan jenis kelamin berpengaruh terhadap bobot badan, panjang badan, tinggi badan,lingkar dada dan panjang ekor. Vestergaard et al. (1995) dalam Rudiono (2007) menyatakan adanya pengaruh hormon testosteron terhadap peningkatan pertumbuhan ternak jantan dikarenakan testosteron memiliki kemampuan untuk merangsang pengeluaran Growth Hormone $(\mathrm{GH})$ 
dari hypophyse dan kemudian testosteron akan bekerja untuk meningkatkan ukuran tubuh pejantan.

Anak rusa jantan memiliki perbedaan morfometri yang besar dengan anak rusa betina, menurut Syawal et al. (2013) menjelaskan bahwa setelah dilahirkan, perkembangan tubuh ternak lebih awal terjadi pada bagian kepala dan kaki, selanjutnya diikuti dengan bagian badan dan bagian punggung yang berkembang lambat dan merupakan bagian yang tumbuh paling akhir dalam mencapai ukuran dewasa. Menurut Subhandiawan et al. (2016), akibat terjadinya laju pertumbuhan yang besar dapat mengakibatkan perbedaan pertumbuhan yang cepat dalam rentang waktu singkat yang disebabkan oleh hormon dan kesehatan ternak.

\section{Panjang badan rusa}

Panjang badan memiliki pengaruh terhadap kelincahan rusa dan kecepatan saat berlari. Menurut Gay (1964) dalam Sipul (2017), ternak yang memiliki panjang badan yang relatif pendek memiliki pergerakan badan yang lebih cepat serta membantu dalam kesinambungan saat bergerak. Panjang badan merupakan bagian dari tubuh rusa yang berdampak akibat terjadinya penambahan bobot badan. Ensminger (1962) dalam Sipul (2017) menjelaskan bertambahnya panjang badan pada tubuh ternak dikarenakan perluasan otot-otot yang menimbun tulang meluas akibat dari penambahan bobot badan.

Perbedaan yang besar terjadi pada perbandingan antara panjang badan rusa jantan dan rusa betina pada kedua penangkaran yaitu $7,66 \mathrm{~cm}$ dan 7,60 $\mathrm{cm}$.Menurut Sudibyo et al. (2012), ukuran tubuh rusa jantan lebih besar dibandingkan dengan ukuran tubuh rusa betina. Penambahan panjang badan sangat dipengaruhi oleh bangsa ternak dan jenis kelamin (Novriani, 2016). Pengetahuan tentang ukuranukuran tubuh ternak dapat digunakan sebagai data untuk menseleksi ternak (Basbeth, 2015).

\section{Tinggi badan rusa}

Tinggi badan merupakan salah satu ukuran tubuh ternak yang dapat digunakan sebagai data pendukung dalam penentuan performa ternak (Novriani, 2016). Pengukuran ukuran tubuh secara umum terhadap rusa timor, rusasambar dan rusa bawean yang dilakukan pada penangkaran rusa di BKPH Jonggol oleh Thohari et al., (1993) menunjukkan bahwa rusa sambar relatif lebih besar dari rusa timor kemudian rusa bawean. Keadaan morfologi rusa sangat dipengaruhi oleh keadaan lingkungan atau habitat rusa (Stefoff, 2008). Akibat dari terjadinya proses pertumbuhan dan untuk menjaga keseimbangan biologis, maka setiap pertumbuhan komponen tubuh akan diikuti dengan peningkatan ukuran-ukuran tubuh (Malewa, 2009).

\section{Lingkar dada rusa}

Secara fisiologis, lingkar dada memiliki pengaruh yang besar terhadap bobot badan karena dalam rongga dada terdapat organ-organ yang akan tumbuh dan mengalami pembesaran sejalan dengan pertumbuhan ternak (Basbeth, 2015). Lingkar dada merupakan bagian dari tubuh rusa yang lebih berpengaruh terhadap bobot badan dibandingkan dengan panjang badan dan tinggi badan. Pada kedua penangkaran terlihat perbedaan yang besar antara rusa jantan dan rusa betina. Peningkatan ukuran lingkar dada terjadi akibat peningkatan kekuatan dan kesuburan otot-otot penggantung Musculus serratus ventralis dan Musculus pectoralis yang ada di daerah dada yang disebabkan penambahan bobot badan (Doho, 1994). Menurut Wahyono et al. (2013), lingkar dada, panjang badan, dan bobot badan memiliki kolerasi yang erat. Penggunaan lingkar dada sebagai seleksi dapat digunakan untuk menentukan sifat ternak yang berhubungan dengan pakan, pertumbuhan dan waktu yang diperlukan untuk mencapai bobot tertentu (Novriani, 2016).

\section{Panjang ranggah rusa}

Rusa jantan memiliki ranggah yang relatif besar, ramping, panjang dan bercabang (Schroder, 1976) dalam Thohari et al., (2011). Ranggah tumbuh dari tonjolan tulang tengkorak yang disebut pedicle dan memiliki bagian dalam yang padat (Suyanto, 2002). Pada siklus pertumbuhan ranggah selama setahun, ranggah akan tanggal dan tumbuh baru. Menurut Mannes (1999), ranggah mempunyai fungsi lain yaitu sebagai simbol status sosial pejantan pada saat musim kawin, selain sebagai alat bertarung. Menurut Mannes (1999), pertumbuhan ranggah dimulai pada usia 8 bulan. Setelah dewasa, ranggah akan menjadi sempurna yang ditandai dengan terdapatnya 3 ujung runcing (Suyanto, 2002). Rusa jantan dewasa memiliki ranggah yang bercabang tiga, dengan ujung-ujungnya yang runcing, kasar dan beralur memanjang dari pangkal hingga ke ujung ranggah (Takandjandji dan Garsetiasih, 2002). 
Menurut Handarini (2006), pertumbuhan ranggah berhubungan dengan tingkat produktivitas ternak. Hal ini dikarenakan rusa jantan mempunyai pola aktivitas reproduksi mengikuti siklus ranggah (annual antler cycle). Pertumbuhan ranggah keras merupakan suatu indikator memasuki musim kawin (Garcia et al., 1997) dalam Handarini (2006) dikarenakan adanya pola peningkatan konsentrasi hormontestosteron dalam plasma darah yang terjadi pada tahap ranggah keras (Bubenik \& Bubenik, 1987). Salah satu faktor yang memengaruhi pertumbuhan ranggah yaitu iklim atau cuaca. Menurut Takandjandji dan Garsetiasih (2002), daerah NTT merupakan daerah beriklim tropis dengan musim kemarau yang panjang sehingga terjadi pergeseran pertumbuhan ranggah keras yang lebih lama yaitu sekitar 9 bulan. Handarini (2006) menjelaskan bahwa hal ini merupakan suatu mekanisme pertahanan daya hidup yang alamiah sesuai dengan kondisi iklim.

\section{Bobot badan}

Pendugaan bobot badan rusa dilakukan dengan menggunakan perhitungan rumus Winter yang membutuhkan variabel lingkar dada dan panjang badan.

Berat Badan $(\mathrm{kg})=\frac{(\mathrm{LD})^{2}(\mathrm{~cm}) \times \mathrm{PB}(\mathrm{cm})}{10000}$

Bobot badan anak rusa timor di kawasan penangkaran Kota Kupang lebih tinggi dibandingkan dengan yang laporkan oleh Adiati dan Brahmantiyo (2015) di Balitnak yaitu anak rusa jantan 5,00 dan

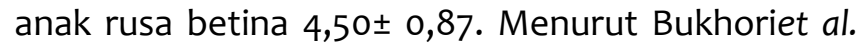
(2017), bobot badan dapat dipengaruhi oleh umur dikarenakan adanya hubungan antar bobot badan dan laju pertumbuhan. Pertumbuhan cepat terjadi dari periode lahir hingga pubertas, namun setelah usia pubertashingga usia dewasa akan menurun dan laju pertumbuhan akan terus menurunhingga usia dewasa.

Bobot badan rusa penting untuk diketahui karena merupakan salah satu indikator penentu produktivitas ternak. Menurut Wahyono et al. (2013), pertumbuhan bobot badan ternak juga dipengaruhi oleh berbagai faktor diantaranya bangsa, jenis kelamin, pakan, kesehatan, berat lahir, berat sapih, sertamanajemen pemeliharaan. Bobot lahir berpengaruh terhadap laju pertumbuhan prasapih. Anak ternak dengan bobot lahir rendah biasanya diikuti oleh rendahnya air susu yang diperolehdari induknya, sehingga laju pertumbuhan sampai disapih terlihat lebih lambat daripadaanak ternak yang bobot lahirnya tinggi (Suryadi, 2012).
Bobot badan yang terlalu besar menandakan asupan gizi yang baik akan tetapi dapat menghambat aktivitas pergerakan rusa sebagai hewan liar yang dikenal dengan hewan yang aktif dan lincah. Sedangkan bobot badan yang kecil menandakan kurangnya asupan gizi yang dibutuhkan. Selain itu juga, diakibatkan oleh kawin sedarah (inbreeding). Menurut Syaputra (2019), dampak negatif akibat pengaruh perilaku inbreeding terhadap ukuran tubuh yaitu sebesar $51 \%$, yang mengakibatkan penurunkan rataan nilai karakteristik yang berhubungan dengan kemampuan reproduksi dan produksi.

\section{Sistem Pemeliharaan}

\section{Lingkungan penangkaran}

Penangkaran rusa terdiri dari sistem penangkaran terkurung (kandang/pedok), semi terkurung (mini ranch), dan sistem bebas (ranch) (Takandjandji, 2014). Mini ranch merupakan habitat buatan dalam kandang penangkaran yang berpagar keliling dilengkapi dengan sumber air, tempat pakan, lapangan perumputan, dan areal pepohonan (Takandjandji, 2014). Kedua kawasan penangkaran berada pada wilayah pemukiman warga. Sanitasi yang kurang sangat berpengaruh terhadap kesehatan ternak seperti yang dikatakan menurut BPTP-Ungaran (2000), sanitasi merupakan suatu kegiatan pencegahan yang meliputi kebersihan tempat tinggal ternak atau kandang dan lingkungannya dalam rangka untuk menjaga kesehatan ternak sekaligus pemiliknya.

\section{Aktivitas rusa}

Berdasarkan hasil penelitian menunjukkan bahwa aktivitas rusa dimulai dari pagi pukul 07.00 WTA hingga sore hari pukul 17.00 WITA meliputi aktivitas: makan, minum, istirahat, dan bergerak. Menurut Santoso (2011), rusa merupakan hewan diurnal atau hewan yang melakukan aktivitas pada siang hari. Dalam melakukan aktivitas harian, sebagian besar waktunya digunakan untuk mencari makan dan istirahat (Setiawan, 2017). Menurut Sofyan (2018), rusa timor memiliki tingkah laku berpindah, istirahat, tidur, makan, sosial, bermain sendiri dan lainnya (grooming, defekasi, urinasi).

Aktivitas meningkat pada musim kawin pada bulan Maret hingga November menurut Pattiselanno et al. (2008), karena kondisi ranggah keras pada rusa timor menandakan rusa sedang dalam siklus kawin. Hal tersebut menyebabkan rusa lebih aktif berkelahi untuk mempertahankan teritori dan mendapatkan pasangan (Mannes, 1999). Akibatnya, 
banyak perkelahian yang terjadi antar rusa jantan yang sering mengakibatkan kematian pada rusa.

Perbedaan jumlah jantan dan betina pada suatu penangkaran sangat mempengaruhi keberhasilan peningkatan reproduksi. Thohari et al. (2011) menjelaskan pada musim kawin pejantan akan menguasai 4-5 ekor betina.. Menurut Bismark et al. (2011), rusa timor mempunyai tingkah laku hirarki dalam kelompok yang terdiri dari pimpinan dan bawahan rusa. Rusa jantan besar dengan ranggah keras umumnya sebagai pimpinan yang membawahi beberapa induk betina dan anak-anaknya.

\section{Manajemen Pakan}

Pakan merupakan salah satu faktor dalam menentukan keberhasilan pengembangan rusa dengan teknik penangkaran(Garsetiasih et al., 2003). Rusa merupakan hewan herbivora atau pemakan tumbuh-tumbuhan (Stefoff, 2008). Rusa timor dalam melakukan aktivitas makan, dapat memanfaatkan rumput-rumputan, dedaunan dan ranting-ranting pohon yang masih muda (Lelono, 2004). Di alam liar apabila berada di padang rumput, rusa termasuk grasser sedangkan pada areal semak dan hutan, rusa merupakan browser (Setiawan, 2017).

Menurut Bunga et al. (2018), faktor yang memengaruhi konsumsi pakan adalah kesehatan, pakan dan lingkungan, serta aktivitas yang juga memengaruhi tingkat konsumsi pakan. Jumlah konsumsi pakan merupakan faktor penentu yang paling penting dalam menentukan jumlah zat-zat makanan yang didapat satwa. Pada satwa yang sedang tumbuh, kebutuhan zat-zat makanan akan bertambah terus sejalan dengan pertambahan bobot tubuh yang dicapai sampai batas umur dimana tidak terjadi lagi pertumbuhan.

Pemberian pakan tidak menggunakan tempat pakan dan frekuensi pemberian pakan hanya satu (1) kali dalam sehari dengan jumlah yang tidak menentu belum sesuai dengan teknik pemberian pakan di penangkaran menurut Takandjandji (2014) yaitu pemberian pakan segar pada rusa timor didasarkan pada perhitungan $10 \% \times$ bobot badan $\times 2$, dengan frekuensi pemberian pakan sebanyak 2 atau 3 kali sehari (pagi, siang, dan sore), dengan pemberian pakan tambahan berupa dedak padi diberikan tiga kali dalam seminggu, sebanyak $0,5 \mathrm{~kg} /$ individu serta pemberian vitamin organik, obat-obatan, dan pupuk organik untuk memacu pertumbuhan dan reproduksi rusa. Akibatnya, pertumbuhan populasi di kedua penangkaran berjalan lambat dengan jumlah kelahiran 1-2 ekor dalam setahun. Menurut Bismark et al. (2011), aspek-aspek yang memengaruhi keberhasilan penangkaran antara lain jumlah individu, sex ratio, perkandangan, pakan, reproduksi, kesehatan, dan pengelolaan.

Pemberian minum dilakukan secara terus menerus dengan menyediakan tempat minum yang terbuat dari ban bekas. Aktivitas minum rusa tidak terlalu tinggi. Rusa timor merupakan rusa tropis yang memiliki kemampuan untuk lebih sedikit mengonsumsi air dibandingkan dengan rusa sambar (Geist, 1998).

\section{Manajemen Reproduksi}

Rusa merupakan satwa liar yang produktif. Usia reproduksi rusa dimulai dari umur 1,5 - 12 tahun, dan rusa dapat bertahan hidup antara umur 15 - 20 tahun (Santoso, 2011). Hasil penelitian Takandjandji et al. (1997), rusa timor di NTT memiliki rata-rata lama birahi yaitu 2,2 hari dengan siklus 20,3 hari dan mengalami dewasa kelamin (pubertas) pada rusa jantan 8 bulan sedangkan pada rusa betina 8,13 bulan. Rusa melakukan perkawinan pertama pada usia rusa jantan 12,7 bulan dan pada rusa betina 15,3 bulan dengan lama kebuntingan 8,4 bulan dan memiliki jarak kelahiran pertama dan kedua 13,25 bulan.

Pada penangkaran ini rusa timor memiliki pola perkawinan inbreeding dengan jumlah kelahiran 1-2 ekor dalam setahun. Menurut Samsudewa et al. (2015), perilaku inbreeding mengakibatkan penurunan ukuran-ukuran tubuh dan ukuran ranggah serta berpengaruh terhadap kecacatan tetap. Sedangkan menurut Takandjandji et al. (1997), tingkat pertambahan anak rusa yang lahir per tahun 0,8 ekor dan ratio kelamin anak yang lahir antara jantan dan betina 1:1,3 ekor, persentase kelahiran sebesar 96,07\% dan tingkat kematian 17,25\%. Berdasarkan hasil wawancara, mengetahui musim kawin rusa ditandai dengan pertumbuhan ranggah keras.

Menurut Semiadi (2006), cara untuk mengetahui rusa memasuki musim kawin dengan mengekstrapolasi bulan tertinggi pejantan dalam keadaan ranggah keras, terdapat bekas torehan ranggah pada tumbuhan sekitar penangkaran, terbentuknya kubangan dan perilaku pejantan dalam menjaga betina. Peningkatan manajemen reproduksi dapat dilakukan dengan pengontrolan terhadap pemberian pakan. Menurut Santoso (2011), hal ini dikarenakan kebuntingan pada rusa betina dapat terjadi apabila berat badan rusa betina telah mencapai minimal $70 \%$ dari berat dewasanya. Semiadi (2006) melaporkan bahwa berat minimal untuk kebuntingan pada rusa timor betina adalah 40-50 kg. 
Secara morfologi, rusa timor jantan memiliki warna dasar kuning kecoklatan pada seluruh area tubuh dan tidak memiliki corak tertentu, sedangkan rusa timor betina memiliki warna coklat keabuan pada area ventral yaitu bagian kaki, perut, dagu dan bagian bawah leher. Perbedaan yang nyata pada rusa timor jantan dan betina terlihat berdasarkan hasil pengukuran bagian-bagian luar tubuh yaitu: bobot badan, lingkar dada, panjang badan, dan tinggi badan. Berdasarkan pengukuran morfometri didapatkan rusa timor dewasa di kota Kupang memiliki ukuran yang lebih besar dibandingkan dengan rusa timor di Manokwari dan anak rusa timor di kota Kupang memiliki ukuran tubuh yang lebih besar dibandingkan dengan anak rusa timor di Ciawi. Sistem pemeliharaan rusa timor pada dua kawasan penangkaran di kota Kupang merupakan penangkaran semi terkurung (mini ranch) yang dipelihara di area pekarangan rumah.

"Penulis menyatakan tidak ada konflik kepentingan dengan pihak-pihak yang terkait dalam penelitian ini".

\section{DAFTAR PUSTAKA}

Adiati U, Brahmantiyo B. 2015. Karakteristik morfologi rusa timor (Rusa timorensis) di Balai Penelitian Ternak Ciawi. Prosiding Seminar Nasional Teknologi Peternakan dan Veteriner. Bogor. p596-600.

Basbeth AH, Dilaga WS, Purnomoadi A. 2015. Hubungan antara ukuran-ukuran tubuh terhadap bobot badan kambing jawarandu jantan umur muda di Kabupaten Kendal Jawa Tengah. Animal Agriculture Journal 4(1): 35-40.

Bismark RM, Mukhtar AS, Takandjandji M, Garsetiasih R, Setio P, Sawitiri R, et al. 2011. Sintesis Hasil-Hasil Litbang: Pengembangan Penangkaran Rusa Timor. Badan Penelitian dan Pengembangan Kehutanan. Jakarta.

Bowling AT, Ruvinsky A. 2000. The Genetics of the Horse. CABI Publishing. London.

BPTP-Ungaran. 2000. Sanitasi Kandang Sapi Perah. BPTP Ungaran. Jawa Tengah.

Brahmantiyo, B. Wirdateti, T. Nugraha, A. Trasidiharta. 2011. Peningkatan bobot badan dewasa rusa sambar melalui seleksi di penangkaran. Buletin Plasma Nutfah 17(1): 68-72.
Bubenik GA, Bubenik AB. 1987. Recent Advances in Studies of Antlers Development and Neuroendocrine Regulation on the Antler Cycle. In: Christen MW (eds). Biology and Management of the Cervidae. p99-111.

Bukhori I, Aka R, Saili T. 2017. Pola pertumbuhan kambing kacang jantan di Kabupaten Konawe Selatan. JITRO 4 (3): 34 - 41.

Bunga R. Kawatu MMH, Wungow RSH, Rompas JJI. 2018. Aktivitas harian rusa timor (Cervus timorensis) di Taman Marga Satwa Tandurusa Aertembaga, Bitung-Sulawesi Utara. Zootec 38(2): 345-356.

Dinas Komunikasi dan Informatika Kota Kupang. 2018. Kupang: Diskeminfo http://v8.kupang Kota.go.id. Download: July 2, 2019.

Dinas Pengendalian Penduduk dan Keluarga Berencana Kota Kupang. 2018. Kupang: Dinas PPKB http://v8.kupangKota.go.id/2018/10/15/opd/. Download: September 4, 2019.

Djanah D. 1984. Menentukan Umur Ternak. CY Yasaguna. Jakarta.

Doho SR. 1994. Parameter Fenotipik Beberapa Sifat Kualitatif dan Kuantitatif pada Domba Ekor Gemuk. Tesis S2. Sekolah Pascasarjana, Institut Pertanian Bogor. Bogor.

Ensminger ME. 1962. Animal Science: Animal Agriculture Series. $5^{\text {th }}$ ed. Printers \& Publishers, Inc. Danville, Illinois.

Fitriyanty $\mathrm{H}$, Burhanuddin Masyud, Agus Priyono Kartono. 2014. Respon rusa timor terhadap pemberian pakan alternatif di penangkaran. Media Konservasi 19 (2): 105-112.

Garsetiasih R, Heriyanto NM, Atmaja J. 2003. Pemanfaatan dedak padi sebagai pakan tambahan rusa. Buletin Plasma Nutfah 9 (2): 23-27.

Geist V. 1998. Deer of the World: Their Evolution Behavior, and Ecology. Stackpole Books. United States of America.

Handarani R. 2006. Pola dan siklus pertumbuhan ranggah rusa timor jantan (Cervus timorensis). Jurnal Agribisnis Peternakan 2 (1): 28-35.

Hardjosubroto W. 1994. Aplikasi Pemuliabiakan Ternak di Lapangan. Gramedia Widiasarana Indonesia. Jakarta.

Idris I, Moin S, Sulah S, Jiwan D. 2000. Some physical characteristics of sambar deer (Cervus unicolor). Pertanika J Trap Agric Sci 23(1): 55-59.

International Union for Conservation of Nature and Natural Reserves. 2018. The Redlist of Threathened Species. UK: IUCN. http://www.iuc nredlist.org. Download: January 31, 2019. 
Kementrian Kehutanan. 2005. Peraturan Menteri Kehutanan Nomor: P. 19/Menhut-II/2005 tentang Penangkaran Tumbuhan dan Satwa Liar. Kementrian Kehutanan Republik Indonesia. Jakarta.

Lelono A. 2004. Ekologi perilaku makan rusa (Cervus timorensis Lyd.) dalam penangkaran di Ranca Upas Ciwidey. Tesis S2. Sekolah Pascasarjana, Institut Teknologi Bandung. Bandung.

Maharani D, Siswadi. 2017. Pengaruh Pemberian Kombinasi Pakan Terhadap Pertumbuhan Rusa Timor (Rusa Timorensis) di KHDTK Rarung Lombok Tengah. Prosiding Seminar Nasional Perhutanan Sosial. Lombok Barat. p263-269.

Mahre MB, Wahid $H$, Rosnina $Y$, Jesse FFA, Jaji $A Z$, Ojo NA et al. 2016. Anatomy of the female reproductive system of Rusa deer (Rusa timorensis). Sokoto Journal of Veterinary Sciences 14 (1):15-20.

Malewa A. 2009.Penaksiran bobot badan berdasarkan lingkar dada dan panjang domba donggala. J Agroland 16: 91-97.

Mannes J. 1999. Pemanenan Ranggah Muda (velvet) Sebagai Tambahan Nilai Usaha Penangkaran Rusa Timor (cervus timorensis de Blainville) Perum Perhutani di Jonggol Jawa Barat. Skripsi S1. Fakultas Kehutanan, Institut Pertanian Bogor. Bogor.

Menteri Pertanian Republik Indonesia. 1990. SK No. 362/KPTS/TN.120/1990 tentang Ketentuan dan Tata Cara Pelaksanaan Pemberian Izin dan Pendaftaran Usaha Peternakan. Departemen Pertanian Republik Indonesia. Jakarta.

Novriani D. 2016. Perbandingan Karakteristik Morfologi Kambing Saburai Jantan pada Dua Wilayah Sumber Bibit di Kabupaten Tanggamus. Skripsi S1. Fakultas Pertanian, Universitas Lampung. Lampung.

Oka GM. 1998. Factors Affecting The Management Of Muntjac Deer (Muntiacus muntjak) in Bali Barat National Park, Indonesia. Hawkesburry. University of Western Sydney. Sydney.

Ordonansi Perlindungan Binatang-binatang Liar. Dierenbeschermings ordonnantie 1931 Staatsblad 1931 Nomor: 134 dan 266.

Pattiselanno F, Isir DA, Takege A, Seseray D. 2008. Kajian awal penangkaran rusa (Cervus timorensis) sistem back yard di Manokwari, Papua Barat. Biosfera 25 (2): 95-100.

Pattiselannolo F, Tethooll AN, Seseray D. 2008. Karakteristik morfologi dan praktek pemeliharaan rusa timor di Manokwari. Berkala IImiah Biotogi 7 (2): 61-67.
Peraturan Pemerintah Nomor 8 Tahun 1999 tentang Pemanfaatan Jenis Tumbuhan dan Satwa Liar.

Primack RB. 1998. Biologi Konservasi. Yayasan Obor. Indonesia. Jakarta.

Rudiyono D. 2007. Pengaruh hormon testosteron dan umur terhadap karakteristik karkas kambing kacang betina. JITV 12(1): 34-41.

Samsudewa D, Setiatin ET, Ondho YS. 2015. Ipteks bagi masyarakat usaha penangkaran rusa timor Desa Margorejo, Kecamatan Dawe, Kabupaten Kudus melalui Pemanfaatan Teknologi Reproduksi. Jurnal Info. 17(2):81-86.

Santoso SI. 2011. Rusa Timorensis (Cervus Timorensis): dari Hewan Konservasi menjadi Hewan Ternak menuju Budidaya. Graha Ilmu. Jakarta.

Semiadi G. 1997. Karakteristik ranggah pada rusa timorensis (Cervus timorensis). Biota 2 (2):82 - 87 .

Semiadi G, Nugraha RTP. 2004. Panduan Pemeliharaan Rusa Tropis. Puslit Biologi LIPI. Bogor.

Semiadi G. 2006. Biologi Rusa Tropis. Lembaga Ilmu Pengetahuan Indonesia. Bogor.

Septian AD, Arifin M, Rianto E. 2015. Pola pertumbuhan kambing kacang jantan di Kabupaten Grobogan. Animal Agriculture Journal 4(1):1-6.

Setiawan T. 2017. Studi Produktivitas Hijauan Sebagai Sumber Pakan Rusa Sambar (Cervus Unicolor) di Penangkaran Rusa PT. Gunung Madu Plantations. Skripsi S1. Fakultas Pertanian, Universitas Lampung. Lampung.

Sipul AUJ. 2017. Studi Keragaman Warna dan Morfometrik Kuda Sandelwood di Kabupaten Sumba Tengah. Skripsi S1. Fakultas Kedokteran Hewan, Universitas Nusa Cendana. Kupang.

Sofyan I. 2018. Studi Perilaku Harian Rusa Timor (Cervus Timorensis) di Penangkaran Rusa Tahura Wan Abdul Rachman. Skripsi S1. Fakultas Pertanian, Universitas Lampung. Lampung.

Stefoff R. 2008. Deer. New York. Marshall Cavendish Benchmark.

Subhandiawan H, Komar SB, Suwarno N. 2016. Persamaan laju pertumbuhan domba lokal jantan dan betina umur 1-12 bulan yang ditinjau dari panjang badan dan tinggi pundak (kasus peternakan domba di Kampung Nenggeng, Desa Neglasari, Kecamatan Darangdan, Kabupaten Purwakarta, Jawa Barat). Students e-Journals 5(4):1-13. 
Sudibyo M, Santosa Y, Masy'ud B, Toharmat T. 2012. Ekologi Habitat Rusa Timor (Rusa Timorensis) di Kawasan Konservasi Pulau Peucang (Tipologi Rusa Timorensis dan Produk Ranggah Muda). Laporan Penelitian. Fakultas Matematika dan Ilmu Pengetahuan Alam, Universitas Negeri Medan. Medan.

Suryadi U. 2012. Pengaruh jumlah anak sekelahiran dan jenis kelamin terhadap kinerja anak domba sampai sapih. Majalah Ilmiah Peternakan 9(1):1-9.

Suyanto A. 2002. Mamalia di TNGH Jawa Barat. BPCJICA. Bogor.

Syamyono O, Purbowati E, Kurnianto E, Samsudewa D, Setiatin ET, Sutopo. 2013. Uji Keakuratan Rumus Pendugaan Bobot Badan Berdasarkan Ukuran Tubuh Pada Kambing Kejobong Jantan Muda dan Dewasa. Proseding Seminar Nasional Peternakan Fakultas Peternakan. Universitas Padjajaran. Bandung.

Syaputra MA. 2019. Efek Silang Dalam (Kawin Sedarah) terhadap Ukuran Tubuh Kerbau Murrah (River buffalo) di Sumatera Utara. Skripsi S1 Fakultas Pertanian, Universitas Sumatera Utara. Medan.

Syawal S, BP Purwanto, IG Permana. 2013. Studi hubungan respon ukuran tubuh dan pemberian pakan terhadap pertumbuhan sapi pedet dan dara. JITP 2 (3):175-188.

Takandjandji M, Sutrisno E, Ganardi D. 1997. Prospek Budidaya Rusa Timor (Cervus timorensis) sebagai Ternak. Proseding Diskusi Hasil-hasil Penelitian BPK. Kupang.

Takandjanji M. Garsetiasih R, 2002. Pengembangan Penangkaran Rusa Timor (Cervus timorensis) dan Permasalahannya di NTT. Proseding Seminar Nasional Bioekologi dan Konservasi Ungulata. Bogor.
Takandjanji M. 2014. Teknik Penangkaran Rusa Timor (Rusa timorensis). Pusat Litbang Konservasi dan Rehabilitasi. Badan Litbang Kehutanan, Kementerian Kehutanan. Jakarta.

Thohari AM, Masy'ud B, Takandjandji M. 2011. Teknis Penangkaran Rusa timor (Cervus timorensis) untuk Stok Perburuan. Seminar Sehari Prospek Penangkaran Rusa Timor (Cervus timorensis) sebagai Stok Perburuan. Bogor. p1-15.

Wahyono T, Kusumaningrum, Widiawati, Suharyono. 2013. Penampilan Produksi Kambing Kacang Jantan yang diberi Pakan Siap Saji (PSS) Berbasis Silase Tanaman Jagung. Seminar Nasional Teknologi Peternakan dan Veteriner. p363-367.

Wilson DE, Mittermeier R.A. 2011. Handbook of the Mammals of the World: Hoofed mammals. Lynx Edicions. Barcelona.

Wiwid R. 2016. Beberapa Pertimbangan dalam Penentuan Warna Kuda di Arthayasa Stable. Universitas Pertanian Bogor. Bogor.

Yusuf M. 2004. Hubungan Antara Ukuran Tubuh dengan Bobot Badan Sapi Bali di Daerah Bima NTB. Skripsi S1. Fakultas Peternakan, Universitas Gadjah Mada. Yogyakarta.

Zaman. 1994. Alternatif Konsep Pembibitan dan Pengembangan Usaha Ternak Kambing. Potensi Ternak Kambing dan Prospek Agribisnis Peternakan. 